\title{
P049: High rate of MRSA respiratory tract colonisation in HIV-positive children in Cambodia during 2004-2012
}

\author{
J Sokolova ${ }^{1,2}$, N Kulkova ${ }^{1,2}$, A Liskova ${ }^{2}$, A Streharova ${ }^{3 *}$, A Shahum ${ }^{4}$, G Benca ${ }^{4}$, V Krcmery ${ }^{2,4}$ \\ From 2nd International Conference on Prevention and Infection Control (ICPIC 2013) \\ Geneva, Switzerland. 25-28 June 2013
}

\section{Introduction}

Children attending child care centres are at increased risk of infections, including those caused by MRSA (methicillin-resistant S. aureus).

\section{Objectives}

The aim of this study was to evaluate MRSA colonization among HIV-infected children in two orphanages in Cambodia during period 2004-2012 and to assess risk of spreading MRSA within these specific health-care facilities.

\section{Methods}

Totally 137 HIV positive children (39,4\% male; median age 7, IQR $=5-9$ ) were enrolled in our HIV programmes during 2004-2012 (follow up 51 \pm 28 months). Every 6 months, respiratory swabs were obtained, followed by organisms' identification and susceptibility testing according to CLSI guidelines.

\section{Results}

We have collected 586 respiratory swabs positive for bacteria. Considering overall aetiology, S. aureus was predominant (178 isolates; 30,4\%), followed by Str. pneumoniae $(103 ; 17,6 \%)$ and K. pneumoniae (99; 16,9\%). M. catarrhalis and $H$. influenzae were present in less extent (35; $6,0 \%$ and $20 ; 3,4 \%$, respectively). In relation to resistance, we found out oxacillin resistance (phenotype MRSA) to be the most prevalent among S. aureus (112 isolates; $63 \%$ ) and resistance to other classes of antibiotics was high in this group of pathogens, too (e.g. clindamycin-59\%; erythromycin-4,3\%). However, susceptibility to some other antibiotics, such as vancomycin, linezolid, ciprofloxacin and co-trimoxazole was very well (100\%; $100 \%$; $96 \%$ and $95 \%$, respectively). Typing of hypervariable region of methicillin resistance gene (HVR-mecA typing) among selected MRSA isolates revealed six different HVR-types, with the type I being the most frequent $(41,2 \%)$.

\section{Conclusion}

Despite the TMP/STX prophylaxis, we found out high rates of MRSA colonisation but resistance to this antibiotic remained rare. This is supporting assumption that prophylaxis is decreasing exposure to other pathogens and consequently, selective pressure of antibiotics, too. Diversity among HVR-mecA-types indicates that MRSA in our study were not spread clonally in this specific healthcare facility.

\section{Disclosure of interest}

None declared.

\section{Author details}

'Department of Laboratory Medicine, Trnava University in Trnava, Trnava, Slovakia. ${ }^{2}$ Laboratory of Molecular Microbiology, St. Elisabeth University, Bratislava, Slovakia. ${ }^{3}$ Department of Public Health, Trnava University in Trnava, Trnava, Slovakia. ${ }^{4}$ St. Maximilian Kolbe Clinic, Phnom Penh, Cambodia.

Published: 20 June 2013

doi:10.1186/2047-2994-2-S1-P49

Cite this article as: Sokolova et al:: P049: High rate of MRSA respiratory tract colonisation in HIV-positive children in Cambodia during 20042012. Antimicrobial Resistance and Infection Control 2013 2(Suppl 1):P49.

${ }_{3}^{3}$ Department of Public Health, Trnava University in Trnava, Trnava, Slovakia

Full list of author information is available at the end of the article

(c) 2013 Sokolova et al; licensee BioMed Central Ltd. This is an Open Access article distributed under the terms of the Creative 